Tymochko O., Larin V., Sheviakov I. Ivan Kozhedub Kharkiv National Air Force University, Kharkiv

Abdalla A. Flying Akademy of the National Aviation University, Kropyvnytskyi

\title{
DEVELOPMENT OF AN ADVANCED METHOD FOR COMPRESSING THE DYNAMIC COMPONENT OF A DIFFERENTIAL-REPRESENTED FRAME
}

\begin{abstract}
For a typical low complexity video sequence, the weight of each P-frame in the stream is approximately three times smaller than the I-frame weight. However, taking into account the number of P-frames in the group, they make the main contribution to the total video data amount. Therefore, the possibility of upgrading coding methods for P-frames is considered on preliminary blocks' type identification with the subsequent formation of block code structures. As the correlation coefficient between adjacent frames increases, the compression ratio of the differential-represented frame's binary mask increases. The compression ratio of the differentialrepresented frame's binary mask varies from 3 to 21 depending on the correlation coefficient between adjacent frames. Estimation of the bit representation's information content of the differential-represented frame's binary mask on the basis of accounting for the nonequilibrium of the bases of the lengths of the binary series does not require an increase in the complexity of the software-hardware implementation. Due to the double-alphabetic power code, the differentialrepresented frame's binary mask is relative to the single-alphabet code will decrease by $17 \%$. The most preferable method for constructing the compact representation technology of the binary masks of frames represented in a differential form is the approach. This is based on the identification and description of the lengths of one-dimensional binary series. A binary series is a consecutive binary elements sequence with the same value. In this case, sequences of identical binary elements are replaced by their lengths. And since the elements of the binary masks of the frames represented in the differential form take only two possible values 0 or 1, it is suggested to form the lengths of the binary series without indicating their level.
\end{abstract}

Keywords: image, redundancy, coding, quantization, matrix, binary mask, data.

Тимочко О.І., Ларін В.В., Шевяков Ю.І. Харківський наиіональний університет Повітряних Сил ім. І. Кожедуба, Харків

Абдалла А. Льотна академія Національного авіаційного університету, Кропивницький

\section{УДОСКОНАЛЕНИЙ МЕТОД КОМПРЕСІЇ ДИНАМІЧНОЇ КОМПОНЕНТИ ДИФЕРЕНЦІЙНО-ПОДАНОГО КАДРУ}

\begin{abstract}
Анотація: Для типової відеопослідовності низької складності вага кожного I -кадру в потоці приблизно в три рази більше ваги Р -кадру. Однак, з огляду на кількість Р-кадрів в групі, вони вносять вагомий внесок в загальний обсяг відеоданих. Таким чином, розглядається можливість модернізаиії методів обробки Р-кадрів в прочесі попереднього виявлення типів блоків з подальшим формуванням структур блокового коду. По мірі збільшення коефіцієнта кореляиії між сусідніми кадрами ступінь компресії двійковій маски диферениійно-поданого кадру збільшується. Ступінь компресії двійковій маски диференційно-поданого кадру змінюється від 3 до 21 в залежності від коефіиієнта залежності між сусідніми кадрами. Оиінка інформативності бітового подання двійкової маски диферениійно-поданого кадру на основі врахування різної ваги основ довжин двійкового ряду не потребує збільшення складності програмно-апаратної реалізації. Через довжину словникового коду потужності двійкова маска диференційно-поданого кадру щуодо одноалфавітного коду зменшиться на 17\%. Найкращим методом побудови технології
\end{abstract}

(C) Tymochko O., Larin V., Sheviakov I., Abdalla A. 2020 
компактного подання двійкових масок кадрів, представлених в диференціальної формі, $\epsilon$ підхід з усуненням надмірності на джерелі інформації. Це засновано на ідентифікації та описі довжин одновимірного двійкового ряду. Двійковий ряд - иче послідовність двійкових елементів з однаковим значенням. В изьому випадку послідовності однакових двійкових елементів замінюються їх довжинами. Оскільки елементи двійкових масок кадрів, представлених в диференційній формі, приймають тільки два можливих значення 0 або 1 , пропонується формувати довжини двійкового ряду без вказівки їх рівня.

Ключові слова: зображення, надмірність, кодування, квантування, матриця, двійкова маска, дані.

Тимочко А.И., Ларин В.В., Шевяков Ю.И. Харьковский национальный университет Воздушных Сил им. Ивана Кожедуба, Харьков

Абдалла А. Летная академия Национального авиационного университета, Кропивницкий

\section{УСОВЕРШЕНСТВОВАННЫЙ МЕТОД КОМПРЕССИИ ДИНАМИЧЕСКОЙ КОМПОНЕНТЫ ДИФФЕРЕНЦИАЛЬНО-ПРЕДСТАВЛЕННОГО КАДРА}

Аннотация: Для типичной видеопоследовательности низкой сложности вес каждого I -кадра в потоке примерно в три раза больше веса $P$-кадра. Однако, учитывая количество Р-кадров в группе, они вносят весомый вклад в общий объем видеоданных. Таким образом, рассматривается возможность модернизации методов обраотки Р-кадров в проиессе предварительного выявления типов блоков с последующим формированием структур блочного кода. По мере увеличения коэффищиента коррелящии между соседними кадрами степень компресси двоичной маски дифференциально-представленного кадра увеличивается. Степень компрессии двоичной маски дифференциально-представленного кадра изменяется от 3 до 21 в зависимости от коэффичиента зависимости между соседними кадрами. Оченка информативности битового представления двоичной маски дифференциальнопредставленного кадра на основе учета неравновесности основ длин двоччного ряда не требует увеличения сложности программно-аппаратной реализации. Из-за двоичного словарного кода мощности двоичная маска дифференциально-представленного кадра относительно одноалфавитного кода уменьшится на 17\%. Наиболее предпочтительным методом построения технологии компактного представления двоичных масок кадров, представленных в дифференциальной форме, является подход с устранением избыточности на источнике информации. Это основано на идентификащии и описании длин одномерного двоичного ряда. Двоичный ряд - это последовательность двоичных элементов с одинаковым значением. В этом случае последовательности одинаковых двоичных элементов заменяются их длинами. Поскольку элементы двоичных масок кадров, представленных $в$ дифференциальной форме, принимают только два возможных значения 0 или 1 , предлагается формировать длины двоичного ряда без указания их уровня.

Ключевые слова: изображение, избыточность, кодирование, квантование, матрица, двоччная маска, данные.

\section{Introduction}

The main difficulty in working with video are large volumes of transmitted information and sensitivity to delays in the video information transmission. Therefore, in order to eliminate the maximum redundancy amount in the formation of the video sequence, 3 types of frames are used: I, $\mathrm{P}$ and $\mathrm{B}$ which form a frame group [1]. For a typical low complexity video sequence, the weight of each P-frame in the stream is approximately three times smaller than the I-frame weight. However, taking into account the number of P-frames in the group, they make the main contribution to the total video data amount. Therefore, the possibility of upgrading coding methods for P-frames is considered on preliminary blocks' type identification with the subsequent formation of block code 
structures.

It has been analysed the predicted frames processing in the MPEG standard and its drawbacks has found during compressing video data.

A method for encoding P-frames with the ability to select the type of blocks processing has been developed, where the structural redundancy estimation of the block is used as a decision rule. Thus, it has been introduced an additional possibility to control the video bit rate by changing the number of I- and P-type blocks [2].

The method of coding and reconstructing predicted frames has been improved by using block coding, which unlike Huffman codes has more noise immunity and less bit and time costs when processing data blocks.

Therefore, it becomes an urgent scientific task to develop of an advanced method for compressing the dynamic component of a differential-represented frame, taking into account the limitations of data processing.

\section{Analysis of literature and problem statement}

A lot of researchers have compared image compression methods. A comparison of international standards for lossless still image compression was made in [3] and in this case they have thoroughly investigated the compression ratio of all the well-known compression methods available at that time. However, the comparison in [4] does not deal with analysis of the latest MPEG standard. Another issue is that consideration is only given to still images.

In [5], the compression ratio and execution time of the compression methods was investigated. in addition, they investigated the efficiency of compression methods based only on textual data and still images. Unmoving images are very different from the dynamic images in a differentialrepresented frame scenario.

Another study on the comparison of compression methods was conducted in [6]. They applied many compression standards and some compression programs to different dynamic images. They have compared both the compression ratio and the execution time of the compression techniques. They have pointed out that the compression performance depends on the type of images and the implication of this is that these results cannot be directly applied to dynamic images in a differential-represented frame scenario because of the different types of obstacles.

An early effort in relation to differential-represented frame scenario has been performed in [7]. Using differential-represented frame scenario, they achieved different qualities for different parts of the image. Using this method an arbitrary ROI in any image can be encoded progressively up to lossless.

A fast and efficient image compression algorithm based on double-alphabetical power code in the classification system of bit processing methods was proposed in [8]. The power code is constructed according to the scheme, which is considered above, is called a two-halftone code. In other words, a two-alphabetic power code is a power code generated for two-alphabetic sequences.

To ensure the timely delivery of video information resources, it is necessary to take into account the high-speed capabilities of communication channels. To do this, data compression algorithms are used. Approaches to creating methods of compact representation can be divided into three classes depending on the requirements for the quality of reconstructed images. These three methods have been best described in [9].

There are two basic strategies for positioning the compressed presentation codograms.

The first strategy is to use marker delimiters between the codograms. Marker delimiters are a code parcel, the contents of which can not be repeated in any one of the codes. On the one hand, this makes it possible to separate the codograms on the receiving side, but on the other hand, this leads to an increase in the volume of the compressed representation.

To eliminate this drawback, it is proposed to use the second strategy. The essence of the second strategy is that the number of digits, for the codogram, is chosen, taking into account the features of the dynamic ranges of the dynamic component's processed lines. 
Formulation of the problem. This paper proposes an approach to develop of an advanced method for compressing the dynamic component of a differential-represented frame, taking into account the limitations of data processing.

\section{The aim of the study}

The aim of the study is to develop of an advanced method for compressing the dynamic component of a differential-represented frame, taking into account the limitations of data processing.

4. Development of an advanced method for compressing the dynamic component of a differential-represented frame

The power code is constructed according to the scheme, which is considered above, is called a two-halftone code. In other words, a two-alphabetic power code is a power code generated for twoalphabetic sequences. In accordance with the properties of the two-alphabetic power code, its place in the classification system of bit coding methods is shown in Fig. 1.
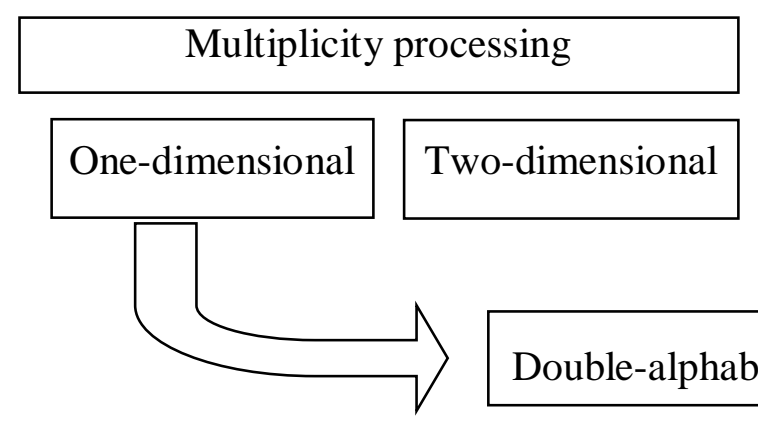

Double-alphabetical power code
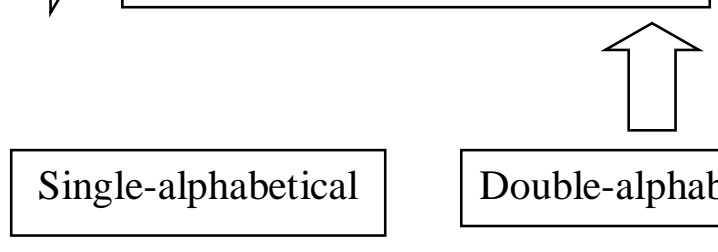

Type of detectable characteristics

The power of the alphabet's processed data

Fig. 1. The place of a Double-alphabetical

power code in the classification system of bit processing methods

Here, the sizes of the binary regions are taken into account as a result of identifying the binary series lengths. It will be shown, that for a two-index power code relative to the binary series lengths of the differential frame's binary mask, the condition holds, i.e. provides a degree of compression:

$$
\eta_{\mathcal{M}}=\frac{m_{\mathcal{M}} n_{\mathcal{M}}}{\Phi_{0} \log _{2} r(0)_{\max }+\Phi_{1} \log _{2} r(1)_{\max }}=\frac{\sum_{i=1}^{\Phi} r_{i}}{\log _{2}\left(r(0)_{\max }^{\Phi_{0} \cdot r(1)_{\max }} \Phi_{1}\right.}
$$

here are $\Phi_{0}$ - the number of the zeros' lengths for the binary mask of the differential-represented frame;

$\Phi_{1}$ - the number of units' series lengths for the binary mask of the differential-represented frame.

An experimental estimate $\eta_{\mathcal{M}}$ of the magnitude of the differential-represented frame's binary mask's array for the video information flow of a stationary camera is shown in Fig. 2. 


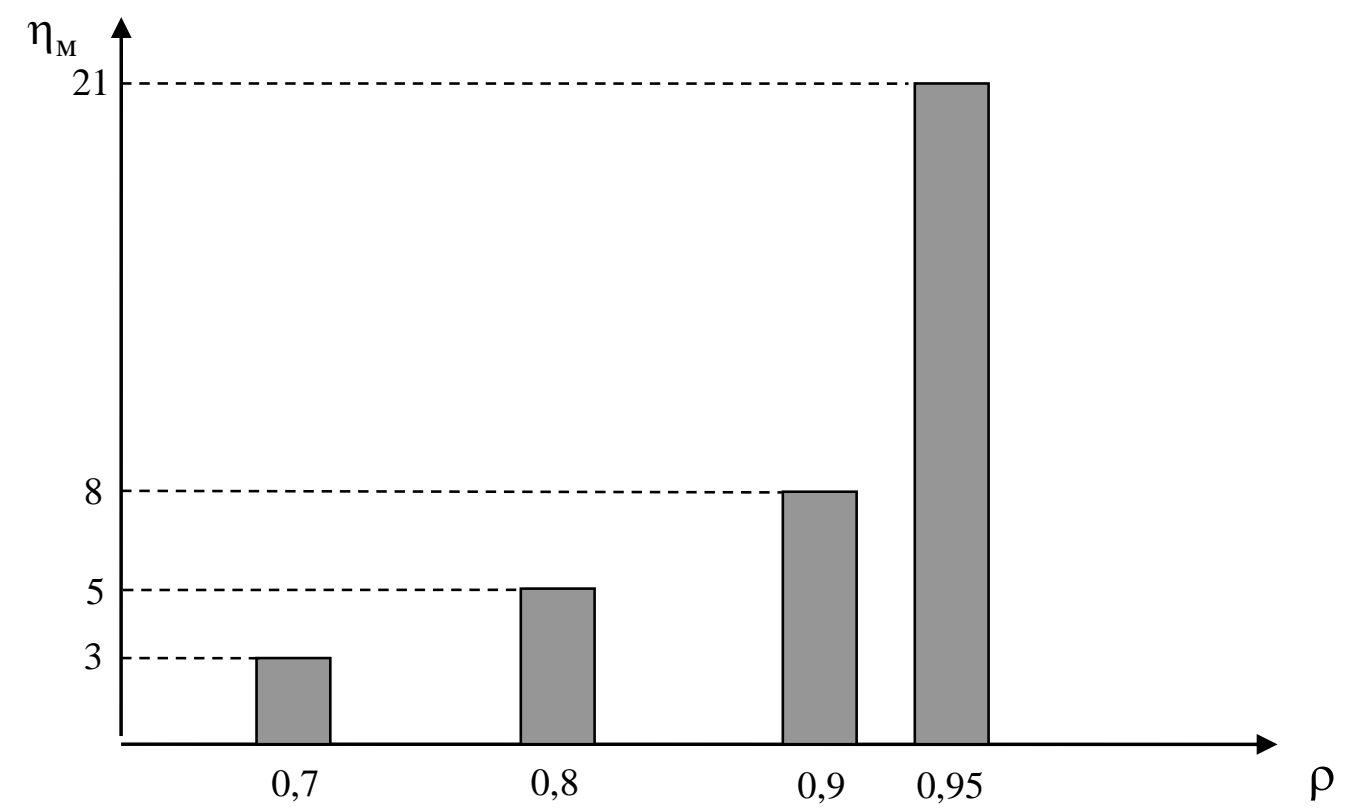

Fig. 2. An experimental estimate of the magnitude of the differential-represented frame's binary mask's array for the video information flow of a stationary camera

Taking into account the revealed features, the structural scheme of the method of doublealphabetical coding of the differential-represented frame's binary mask's matrix is shown in Fig. 3.

Example 1. Let's calculate the number of digits $L(r)_{\Sigma}$ in order to represent the entire sequence of series lengths for the binary mask of the differential-represented frame Q due to a onerate power code.

The binary mask of the differential-

represented frame $\mathrm{Q}$

\begin{tabular}{|l|l|l|l|l|l|}
\hline 0 & 0 & 0 & 0 & 0 & 0 \\
\hline 0 & 0 & 0 & 0 & 0 & 0 \\
\hline 0 & 0 & 0 & 0 & 0 & 0 \\
\hline 0 & 1 & 0 & 0 & 0 & 0 \\
\hline 1 & 1 & 1 & 1 & 1 & 0 \\
\hline 1 & 1 & 1 & 0 & 0 & 0 \\
\hline
\end{tabular}

First, let's define the maximum value of the binary series length $r_{\max }$ in a sequence of binary series lengths $\Theta=\left\{r_{1}=19 ; r_{2}=1 ; r_{3}=4 ; r_{4}=5 ; r_{5}=1 ; r_{6}=3 ; r_{7}=3\right\}$, which is based on expression:

$r_{1}=19 ; L(r)_{1}=5$ bits; $r_{2}=1 ; L(r)_{2}=1$ bit;

$r_{3}=4 ; L(r)_{3}=2$ bits; $r_{4}=5 ; L(r)_{4}=3$ bits;

$r_{5}=1 ; L(r)_{5}=1$ bit; $r_{6}=3 ; L(r)_{6}=2$ bits;

$r_{7}=3 ; L(r)_{7}=2$ bits.

The maximum binary mask series length of a differential-represented frame $r_{\max }=19$. Then, on the basis of expression, the number of bits required to represent the maximum binary mask series length is equal to $L(r)=5$ bits. 


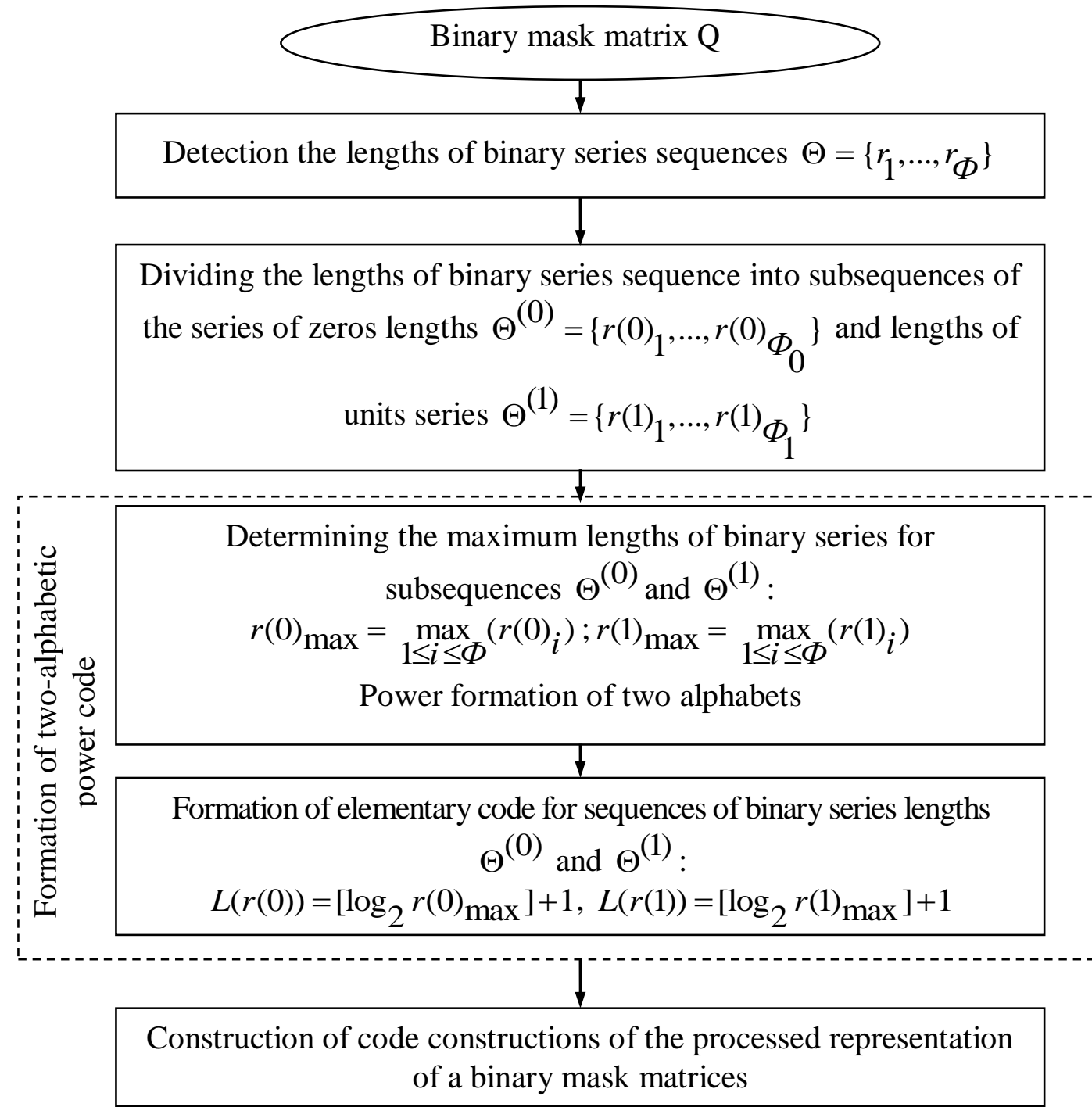

Fig. 3 - Block diagram of the two-alphabetic coding method of the binary mask of a differentially represented frame

The number of the binary series lengths is formed for the differential frame's binary mask's array $\Phi=7$. Then, on the basis of the expression the total number of bits on the representation of the binary series lengths sequence will be equal to a $L(r)_{\Sigma}=5 \cdot 7=35$ bits.

At the same time, 36 digits are required for the code representation of the original image fragment (the image fragment is classified as highly saturated with details having different dynamic components) [10]. Consequently, by applying a single-alphabetic power code for all sequences of series lengths, the binary mask size of the differential-represented frame will be reduced by $3 \%$.

Example 2. Let's calculate the total number of digits $L(r)_{\Sigma}$ for representing the entire sequence of series lengths for the binary mask of the differential-represented frame $\mathrm{Q}$ due to the two-waved power code.

The binary mask of the differential-represented frame Q

\begin{tabular}{|l|l|l|l|l|l|}
\hline 0 & 0 & 0 & 0 & 0 & 0 \\
\hline 0 & 0 & 0 & 0 & 0 & 0 \\
\hline 0 & 0 & 0 & 0 & 0 & 0 \\
\hline 0 & 1 & 0 & 0 & 0 & 0 \\
\hline 1 & 1 & 1 & 1 & 1 & 0 \\
\hline 1 & 1 & 1 & 0 & 0 & 0 \\
\hline
\end{tabular}


First of all, let's define the maximum value $r(0)_{\max }$ in the subsequences of the lengths of the zeros series $\Theta^{(0)}=\left\{r(0)_{1}=19 ; r(0)_{2}=4 ; r(0)_{3}=1 ; r(0)_{4}=3\right\}$ based on the expression:

$$
\begin{aligned}
& r(0)_{1}=19 ; L(r(0))_{1}=5 \text { bits; } \\
& r(0)_{2}=4 ; L(r(0))_{2}=2 \text { bits; } \\
& r(0)_{3}=1 ; L(r(0))_{3}=1 \text { bit; } \\
& r(0)_{4}=3 ; L(r(0))_{4}=2 \text { bits. }
\end{aligned}
$$

The maximum zeros series' length of a binary mask of a differential-represented frame $r(0)_{\max }=19$. Then the number of bits required to represent the maximum length of zeros series of a binary mask is equal to $L(r(0))=5$ bits.

The number of lengths of zeros series is formed for the array of the differential frame's binary mask is equal to $\Phi=4$, then, on the basis of expression the total number of bits for the representation of the subsequence of the zeros lengths will be equal to $L(r(0))_{\Sigma}=5 \cdot 4=20$ bits.

Then, in the same way, let's define the maximum value $r(1)_{\max }$ in the subsequences of the lengths of the ones series $\Theta^{(1)}=\left\{r(1)_{1}=1 ; r(1)_{2}=5 ; r(1)_{3}=3\right\}$ based on the expression:

$$
\begin{aligned}
& r(1)_{1}=1 ; L(r(1))_{1}=2 \text { bits; } \\
& r(1)_{2}=5 ; L(r(1))_{2}=3 \text { bits; } \\
& r(1)_{3}=3 ; L(r(1))_{3}=2 \text { bits. }
\end{aligned}
$$

The maximum length of the series of units of binary masks differential represented frame $r(1)_{\max }=5$. Then the number of bits per representation of the series' maximum length of binary mask units is equal to $L(r(1))=3$ bits.

The number of lengths of the units' binary series formed for the array of the differential frame's binary mask $\Phi=3$. Then, basing on the expression the total number of bits on the series length representation of the units series will be equal to $L(r(1))_{\Sigma}=3 \cdot 3=9$ bits.

Then the total number of bits per representation of the zeros and ones series will be equal to $L(r)_{\Sigma}=L\left(r(0)_{\Sigma}+L(r(1))_{\Sigma}=20+9=29\right.$ bits.

At the same time, 36 bits are required for the code representation of the original image fragment (the image fragment is classified as highly saturated with details having different dynamic components) [11]. Therefore, due to the use of a double-alphabetic power code for the subsequences of the lengths of zeros and ones series. The differential-represented frame's binary mask volume will decrease by $20 \%$. Also, due to the double-alphabetic power code, the volume of the differential-represented frame's binary mask is relative to the single-alphabet code will decrease by $17 \%$.

Basing on the above material it is possible to draw such conclusions:

1. As the correlation coefficient between adjacent frames increases, the compression ratio of the differential-represented frame's binary mask increases.

2. The compression ratio of the differential-represented frame's binary mask varies from 3 to 21 depending on the correlation coefficient between adjacent frames.

3. Estimation of the bit representation's information content of the differential-represented frame's binary mask on the basis of accounting for the nonequilibrium of the bases of the lengths of the binary series does not require an increase in the complexity of the software-hardware implementation.

4. Due to the double-alphabetic power code, the differential-represented frame's binary mask is relative to the single-alphabet code will decrease by $17 \%$. 
Positional coding with adaptive choice of the base is not subjected to individual elements, but their aggregates (rows). Therefore, before starting positional coding with adaptive choice of the base, it is required to form arrays from individual elements.

The dynamic component $I_{d}$ is divided into arrays, as shown in Fig. 4.

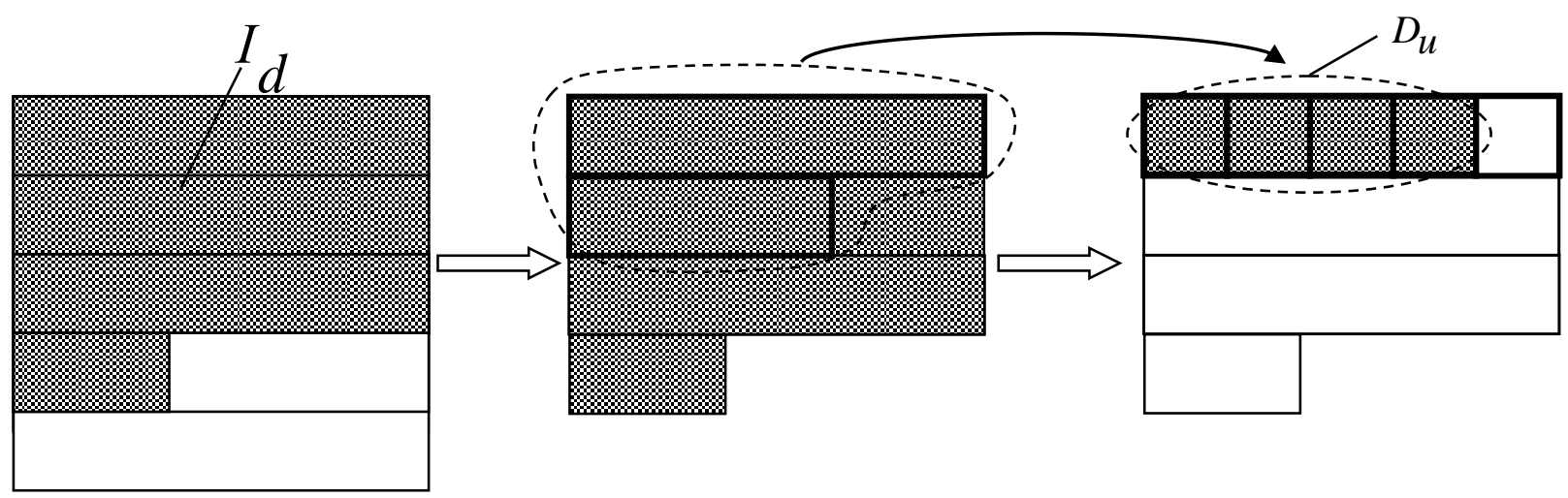

Fig. 4. Segmentation of the dynamic component into arrays

The order of bypassing the dynamic component affects on the arrays $\mathrm{D}$ formation time. From a technical point of view, the shortest display time of information on the screen is achieved with a line by line order of the dynamic component traversal. This is due to the fact that during the display of the image it is displayed on the screen by lines (horizontal scan) [12]. Then, when the image is restored, it will be displayed as the elements belonging to the dynamic component are restored. In this case, the dynamic component is divided into blocks of equal sizes (Figure 5).

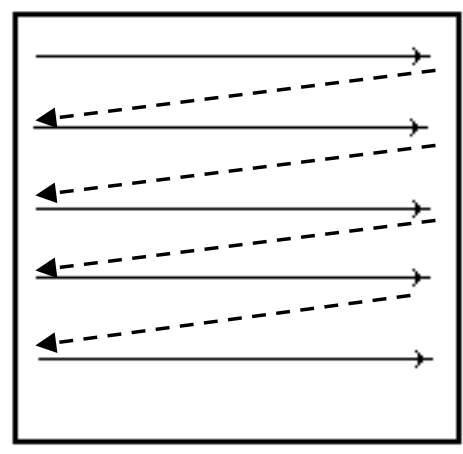

Fig. 5. Fragment of the partitioning of the dynamic component:

$\longrightarrow \quad$ - the direction of the dynamic component traversal

Therefore, it is suggested to organize the order of the dynamic component traversal by rows in the direction from the left to the right. For each subsequent dynamic component $I_{d}$, the process of splitting it into arrays starts from the beginning.

The number of elements in the dynamic component $v_{d}$ is known to us and it is defined as the number of unit elements in the stationary component $I_{S}$. Therefore, it is proposed to break the dynamic component into arrays, taking into account the availability of information on the number of elements of the dynamic component. Hence, the size of the array is suggested to be chosen, with taking into account:

1. The maximum filling of arrays with elements of the dynamic component i.e., in the last array formed for the dynamic component, there should be as few empty lines as possible. 
2. Taking into account that the positional number and the code are formed for the row of the array. In this case, it is necessary to ensure that there are no situations resulting in overflow of the maximum permissible codeword length.

3. Taking into account that the amount of potential reduced redundancy increases with the size of the positional number. This is due to the fact that for a longer block length it is possible to reveal more regularities used in the process of reducing redundancy.

In this connection, the following procedure is proposed for determining the sizes of arrays to which the dynamic component is divided:

1) if the length of an allowable codeword is limited to 64 bits, then according to the positional encoding properties, the length of the string of the dynamic component array must not exceed 8 . On the other hand, in accordance with the third requirement regarding the choice of the size of the dynamic component array, the line length must not be less than 4 . Therefore, in the first stage, it is suggested to choose the length of the line of arrays of the dynamic component equal to 6 , i.e. $\left(n_{d}=6\right)$, if $n_{d} \leq v_{d}$,

here $v_{d}$ is the number of elements in the dynamic component [13].

Then the total number of lines of the dynamic component $m(\Sigma)_{\mathbf{d}}$ when taking into account the knowledge of the value $v_{d}$ is determined by the formula:

$$
m(\Sigma)_{d}=\left\{\begin{array}{cc}
{\left[\frac{v_{d}}{n_{d}}\right]+1,} & \text { if } v_{d}-\left[\frac{v_{d}}{n_{d}}\right] m_{d} \neq 0 ; \\
\frac{v_{d}}{n_{d}}, & \text { if } \quad v_{d}-\left[\frac{v_{d}}{n_{d}}\right] m_{d}=0,
\end{array}\right.
$$

here are $\frac{v_{d}}{n_{d}}$ - the number of lines of the dynamic component, on the basis of which complete arrays are formed;

$v_{d}-\left[\frac{v_{d}}{n_{\mathrm{d}}}\right] m_{\mathrm{d}}-$ the remaining number of lines of the dynamic component, on the basis of which it is impossible to form a complete array;

2) the total number of rows is divided into separate arrays. Here it is necessary to take into account that the number of rows in arrays should be the same. On the other hand, the choice of the number of rows in an array is influenced by the condition of preserving the properties homogeneity in the local area by dynamic ranges. This will allow to choose the adaptive base of the positional number, which most adequately describes the property of the local area. In this connection, it is suggested to choose the number of rows in the array is equal to $n_{d}=6$. Then the number of arrays $v_{\mathcal{M}}^{(d)}$ into which the entire dynamic component is divided is determined by the formula:

$$
v_{\mathcal{M}}^{(d)}=\left[\frac{m(\Sigma)_{\mathrm{d}}}{m_{\mathrm{d}}}\right]
$$

In order to reduce the number of bases of positional numbers that are selected for each array individually, the following procedure is proposed: 


$$
m(\Sigma)_{\mathrm{d}}-\left[\frac{m(\Sigma)_{\mathrm{d}}}{m_{\mathrm{d}}}\right] m_{\mathrm{d}}<3
$$

Then the last full array is filled with the remaining rows from the incomplete array.

Otherwise, when

$$
m(\Sigma)_{\mathrm{d}}-\left[\frac{m(\Sigma)_{\mathrm{d}}}{m_{\mathrm{d}}}\right] m_{\mathrm{d}} \geq 4
$$

An incomplete array is formed.

In general, the scheme for positional coding of arrays of dynamic components with adaptive choice of the base is shown in Fig. 6.

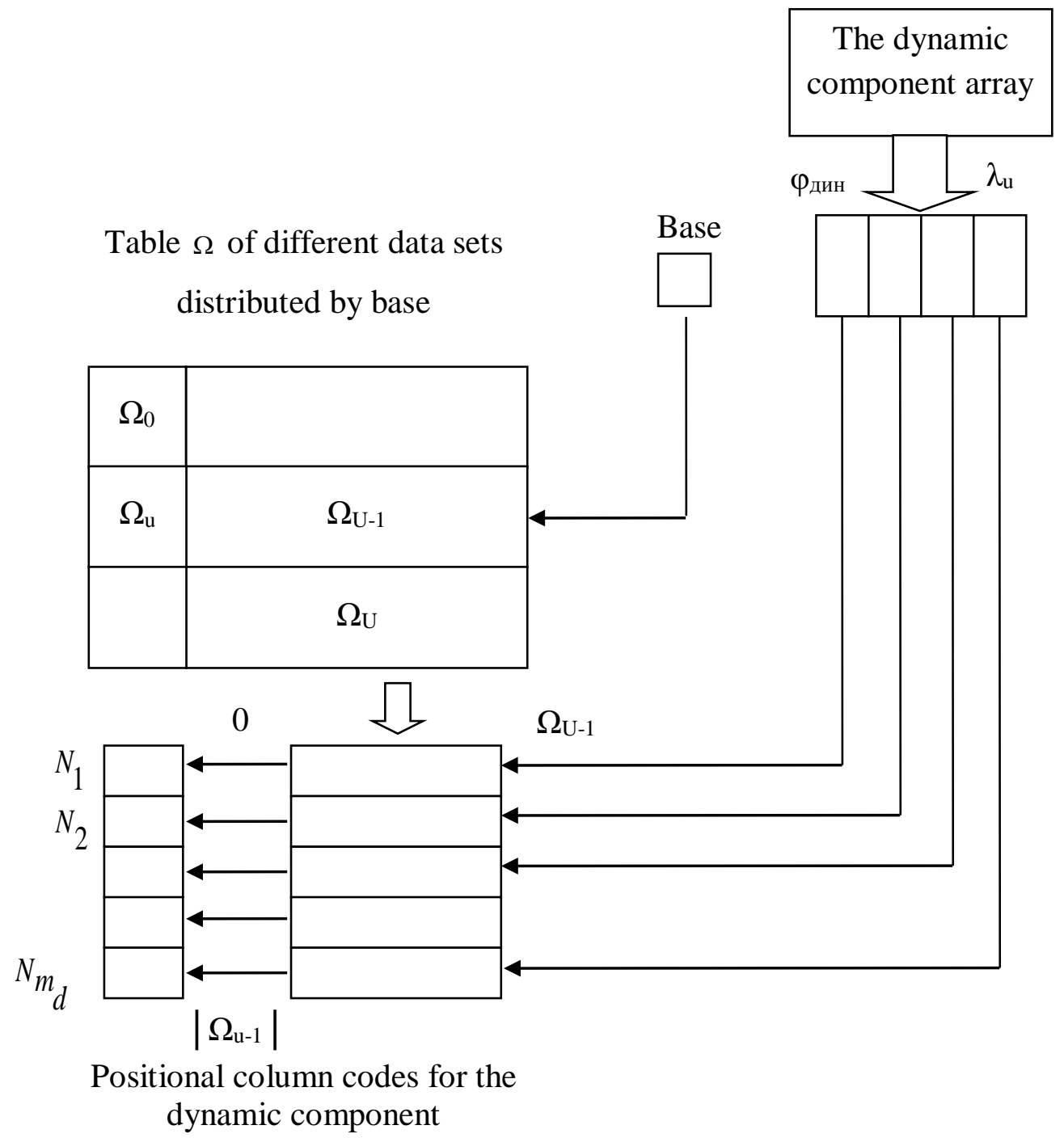

Fig. 6. The scheme of positional coding of dynamic component's array with adaptive choice of base

The table is made up of all possible data sets (in general form), distributed depending on the value of the base, where $U+1$ is the number of the different dynamic component's arrays of a given size. $U$ is the index of the subset of the dynamic component arrays that satisfy the base value $\lambda_{u}$. The arrays of the dynamic component are formed from the original image based on the functionals $\phi_{d}$. Then for the received arrays there is a base $\lambda_{u}$. The found base serves as an input parameter 
for reading from the table $\Omega$ the sets $\Omega_{u}$ of the possible arrays of the dynamic component, respectively. Within the selected sets $\Omega_{u}$, the columns of arrays of the dynamic component are numbered in order from 0 to $\left|\Omega_{u}\right|$, respectively. Therefore, due to the comparison of specific arrays of the dynamic component to the columns of sets $\Omega_{u}$, the corresponding codes for positional numbers $N(u)_{i}$ are determined (Figure 6).

In the general case, the full array $D_{u}$ of the dynamic component has the form:

$$
D_{u}=\left|\begin{array}{cccccc}
d_{1,1} & d_{1,2} & \ldots & d_{1, j} & \ldots & d_{1, n_{d}} \\
& \ldots & & & \\
d_{i, 1} & d_{i, 2} & \ldots & d_{i, j} & \ldots & d_{i, n_{d}} \\
& \ldots & & & \\
d_{m_{d}, 1} & d_{m_{d}, 2} & \ldots & d_{m_{d}, j} & \ldots & d_{m_{d}, n_{d}}
\end{array}\right|,
$$

here are $d_{i, j}$ - element of the array of the dynamic component;

$m_{d}, n_{d}$ - number of rows and columns in the arrays $D_{u}$, respectively.

It needs to be noted that the array $D_{u}$ may not be full.

Formation of a line of the dynamic component's array is carried out, taking into account a shift, by the number of elements equal to the length of the array line $n_{d}$.

The process of partitioning the dynamic component into arrays $D_{u}$ is affected by the maximum value $d_{\max }$ of the element $I_{d}$ and the number of columns $n_{d}$. This is due to the fact that the code is generated not for a separate element of the dynamic component, but for the string of the dynamic component array [14]. Therefore, the values of the positional number code $N(u)_{i}$ and the length of its codogram $L_{i}$ are affected by the adaptive base, which is selected in accordance with the value $d_{\max }$ and number of elements in the positional number, which is determined by the value $n_{d}$. In this case, we can control only the quantity. The value $d_{\max }$ is determined separately for each dynamic component. In this regard, before choosing a value $n_{d}$, it is proposed to consider the features of positional coding with adaptive choice of the base.

The first feature is the restriction, which is imposed on the length of the codogram $L_{j}$, which is assigned to the positional number $N(u)_{j}$. Execution of this restriction is necessary to avoid loss of information due to a lack of bits to represent the value of the code $N(u)_{j}$. For this purpose, the maximum possible number that can be stored in the codogram $L_{j}$ of the digits should not exceed the value of the dynamic range $D_{(N)}$ of values of positional number codes, i.e.:

$$
2^{L}{ } \geq D_{(N)},
$$


here $2^{L} j$ is the maximum possible number, which can be stored in the codogram with a length $L_{j}$ of bits.

Dynamic range $D_{(N)}$ is defined as the maximum possible code of positional numbers $N(u){ }_{j}$ for a given value of the base $\lambda_{u}$.

The second feature is caused by the fact that code values $N(u)_{i}$ are generated for positional numbers of uniform length $n_{d}$. This is due to the fact that the positional number is formed on the basis of the elements of individual rows of the dynamic component's arrays. Therefore, the code values $N(u)_{j}$ will take different values for different strings. Hence, in order to reduce the code redundancy, it is suggested that the length of the codogram $L_{j}$ be chosen to be uneven, i.e. $L_{j}=V A R$.

For the proposed organization of arrays $D_{u}$, the scheme for calculating the positional numbers for the rows $D_{u, j}=\left\{d_{1, j} ; d_{2, j} ; \ldots ., d_{i, j}, \ldots d_{j, m_{d}}\right\}$ of these arrays, taking into account the adaptive choice of the base $\lambda_{u}$, is given by the expressions:

$$
\begin{gathered}
N(u)_{j}=\sum_{j=1}^{m} d d_{i, j} P_{j} ; \\
P_{j}=\lambda_{u}^{\left(m_{d}-j\right)} ; \\
\lambda_{u}=\max _{\substack{1 \leq j \leq n \\
d \\
1 \leq i \leq m}}\{d\}+1,
\end{gathered}
$$

here are $N(u)_{j}$ the code value for the $\mathrm{j}$-th positional number of the $\mathrm{j}$-th column of the $\mathrm{u}$-th dynamic array;

$P_{j}$ - weight coefficient of the $\mathrm{j}$-th element of the positional number;

$\lambda_{u}$ - the base of the $u$-th array of the dynamic component.

Let us consider an example of calculating codes for the positional numbers of rows of a dynamic component's array.

Example 3. Let's calculate $N(u)_{j}$ for the codes of positional numbers of arrays $D_{u}$ :

$$
D_{u}=\left|\begin{array}{ccc}
10 & 23 & 30 \\
20 & 18 & 9 \\
4 & 10 & 15
\end{array}\right|
$$

First, let's define the positional numbers for the rows of the dynamic component array $D_{u, i}$. In order to do this, let's find the basis $\lambda_{u}$ and calculate it by the formula (2) their accumulated 
products $P_{j}$. The value of the base $\lambda_{u}=31$. Then the weighting factor $P_{1}=31^{2}=961$; $P_{2}=31^{1}=31 ; P_{3}=31^{0}=1$. On the basis of these values, using formula (1), let's calculate the values $N(u)_{j}$ for the codes of positional numbers $D_{u, j}$ :

$$
\begin{gathered}
N(u)_{1}=10 \times 961+20 \times 31+4 \times 1=10234 ; L_{1}=14 \text { bits; } \\
N(u)_{2}=23 \times 961+18 \times 31+10 \times 1=22671 ; L_{2}=15 \text { bits; } \\
N(u)_{3}=30 \times 961+9 \times 31+15 \times 1=29124 ; L_{3}=15 \text { bits. }
\end{gathered}
$$

The maximum number of bits being used to represent the positional numbers of the dynamic component is 15 bits. At the same time, 24 bits are required for the code representation of the original image fragment (the fragment is classified as highly saturated with dynamic components). Therefore, due to positional coding, the dynamic component volume will decrease by $38 \%$.

Positional codes will make it possible to compactly represent arrays of the dynamic component if the corresponding maximum values $\lambda_{u}$ have limited values, i.e.: $\lambda_{u}<d_{\max }, u=\overline{1, v_{d}}$. Here is the maximum numerical value of the dynamic component.

Thus, as a proposed encoding result, arrays of the dynamic component are replaced by a sequence of code values of positional numbers with an adaptive base $\left\{N(u)_{1}, \ldots N(u)_{j}, \ldots N(u)_{m_{d}}\right\}$.

Let's consider the interpretation of the proposed encoding. Each line of the dynamic component array, considered as a positional number, is associated with one code $N(u)_{j}$ of uneven length. Then it is clear, that due to positional coding with an adaptive base, the dynamic component's uniform parts are replaced by codograms of uneven length. Therefore, the whole chain of successive transformations can be considered as a uniform vector quantization followed by a non-uniform distribution of the number of binary digits (Fig. 7).

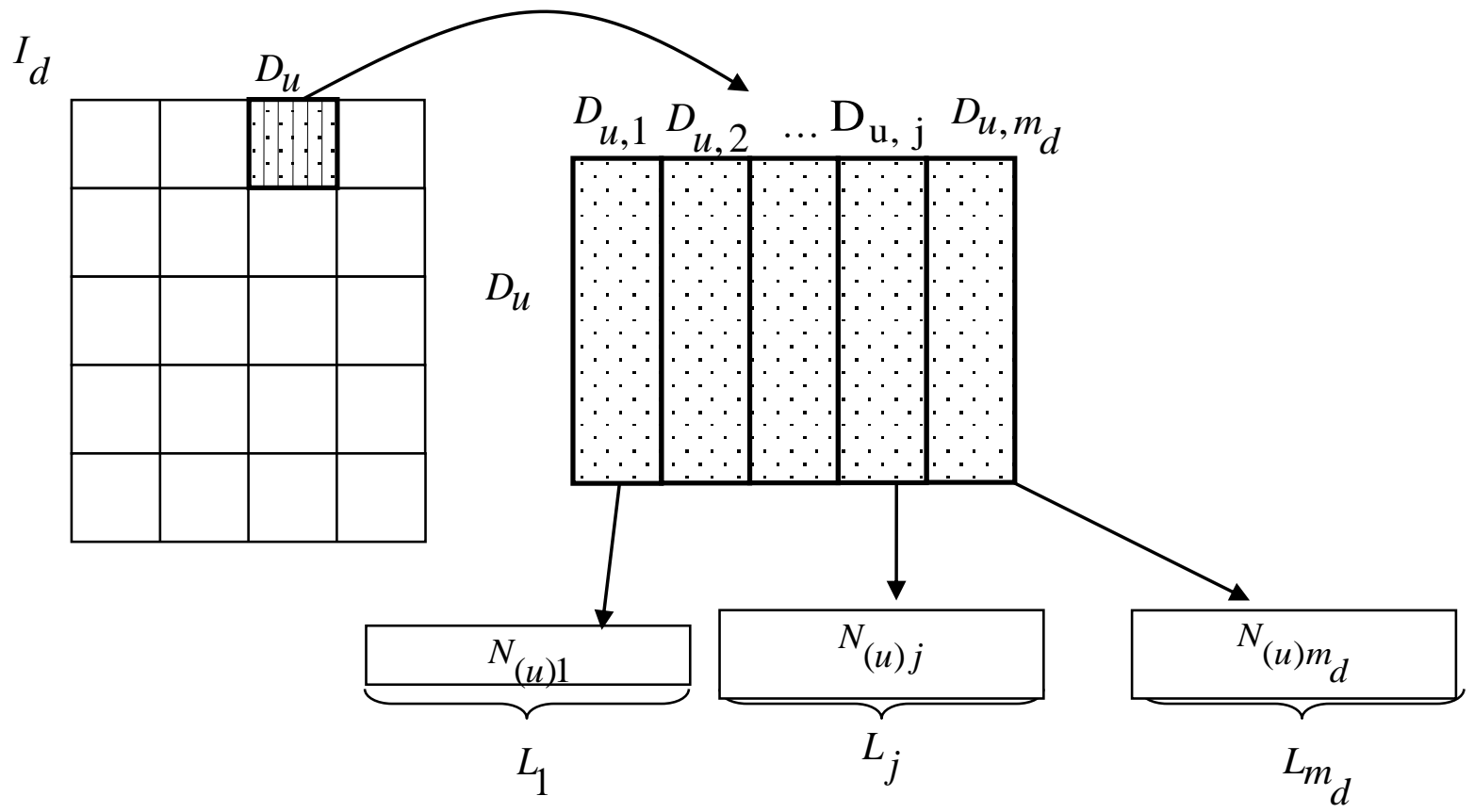

Fig. 7. The scheme of code getting - the image's fragment part's numbers

Let's consider this by the following way: 


$$
\begin{gathered}
N(u)_{j}=f_{e v}\left\{D_{u, j} ; \lambda_{u}\right\} ; \\
L_{j}=f_{p n}\left\{N_{u, j} ; \delta_{u}\right\}=f_{p n}\left\{f_{e v}\left\{D_{u, j} ; \lambda_{u}\right\} ; \delta_{u}\right\},
\end{gathered}
$$

here are: $f_{e v}$ - the functional, which sets equal vectoring of dynamic value;

$f_{p n}$ - the functional, which describes the process of managing by number of binaric for each code of positional number.

Because on the one hand, the number of elements in the position number is uniform, on the other hand the value of their elements is the uneven distribution of natural-axis, the value of the code $N(u)_{j}$ will be uneven, i.e. $N(u)_{j}=V A R$.

In this case, if for each code to form a codogram of a predetermined uniform length $L_{c}$, code redundancy $R_{C}$ will be generated. This is due to the appearance of insignificant high-order bits of the codogram, as shown in Figure 8:

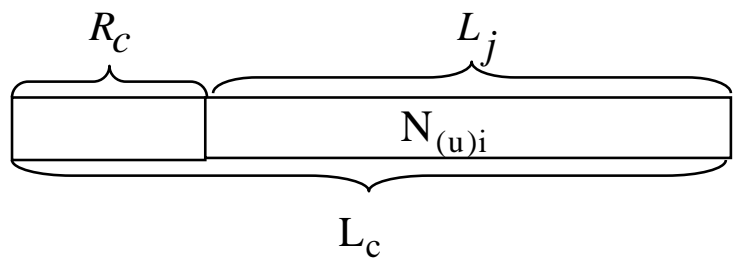

Fig. 8. Code redundancy formation scheme

Code redundancy $R_{C}$ is defined by the following formula:

$$
R_{C}=L_{c}-L_{j}
$$

here are $L_{j}$ - the number of digits representing the value of the positional number code is generated adaptively for each column of the dynamic component array $D_{u}$;

$L_{C}$ - the preselected uniform length of the codogram, which does not take into account the structural features of the dynamic component's arrays $D_{u}$.

In this connection, to reduce the code redundancy, it is proposed to form the length of the codogram, taking into account the structural features of each column $D_{u, j}$ of the dynamic component array. In this case, it is necessary to take into account that the length of the codogram will be uneven, that is, for each row of the dynamic component array, in general, the following inequality can be fulfilled:

$$
L_{1} \neq \ldots L_{j} \neq \ldots L_{m}
$$

For these conditions, there are two basic strategies for positioning the compressed presentation codograms.

The first strategy is to use marker delimiters between the codograms. Marker delimiters are a code parcel, the contents of which can not be repeated in any one of the codes. On the one hand, this makes it possible to separate the codograms on the receiving side, but on the other hand, this leads to an increase in the volume of the compressed representation. 
To eliminate this drawback, it is proposed to use the second strategy. The essence of the second strategy is that the number of digits, for the codogram, is chosen, taking into account the features of the dynamic ranges of the dynamic component's processed lines. At the same time, it is proposed to use only the service information, which is used in the code $N(u)_{j}$ generation process in order to reduce the service data.

In case of code generation for a positional number, it is suggested to consider the following properties.

The maximum code value $N(u)_{\max }$ of a positional number for a given base $\lambda_{u}$, is determined by the accumulated product of its elements' bases, i.e.:

$$
N(u)_{\max }=\lambda^{m} d-1
$$

Where the code value $N(u)_{j}$ for positional numbers with the adaptive base $\lambda_{u}$ will be limited by the following value:

$$
N(u)_{j} \leq \lambda^{m} d-1
$$

Hence the number of binary digits $L_{j}$ to represent the code $N(u)_{j}$ on the adaptive base $\lambda_{u}$ will have the following upper bound:

$$
L_{j}=\left[\log _{2} N(u)_{j}\right]+1 \leq\left[\log _{2} \lambda^{m} d-1\right]+1
$$

As follows from (4), the right-hand side of the inequality depends on the adaptive base's size $\lambda_{u}$ and the column's length $\lambda_{u}$ of the dynamic component array. The value $\lambda_{u}$ is used in the encoding process, i.e. is not additional service information, therefore, to position the positional number codograms, it is proposed to distribute the number of bits for each code according to inequality (4). In this case, the length of the codogram $L_{j}$ will be:

$$
L_{j}=\left[\log _{2} \lambda^{m} d-1\right]+1
$$

then $\delta=\lambda_{u}$.

According to the proposed strategy, the number of digits for each codogram within a single dynamic array will be constant. But for different arrays of the dynamic component, the cost of the number of digits for each codogram will be uneven. This is because there will be differences in the meaning of the bases $\lambda_{u}$. Therefore, the principle of distributing the number of digits for the codogram is called locally uniform.

\section{Conclusions}

Thus, it is possible to draw the following conclusions:

1) the requirements are proposed for splitting the dynamic component into arrays, taking into account, on the one hand, the need for an additional reduction in redundancy, on the other hand, the elimination of cases of codeword overflow;

2) it has been developed the method of compression of dynamic component's arrays is based on one-dimensional positional coding with adaptive choice of the basis, the code of the positional 
number is formed for individual rows of the dynamic component array, and the length of the codeword is chosen unevenly;

3) the codeword lengths are positioned relative to one another in accordance with the known value of the positional number length and the adaptive base.

\section{Literature}

1. Larin V. Development of an advanced method of video information resource compression in navigation and traffic control systems. / S. Yevseiev, Ahmed Abdalla, S. Osiievskyi, V. Larin, M. Lytvynenko. // EUREKA: Physics and Engineering 5.(2020), P. 31-42. https://doi.org/ 10.21303/2461-4262.2020.001405.

2. Ruban I. Method of neural network recognition of ground-based air objects. / I.Ruban, K.Smelyakov, N.Bolohova // Proceedings of 2018 IEEE 9th International Conference on Dependable Systems, Services and Technologies, DESSERT 2018, pp. 589-592.

3. Sumtsov D. Development of a method for the experimental estimation of multimedia data flow rate in a computer network. / D.Sumtsov, S.Osiievskyi, V. Lebediev // Eastern-European Journal of Enterprise Technologies. Volume 2, Issue 2-92, 2018, Pages 56-64.

4. Mistry D. Network traffic measurement and analysis. / D.Mistry, P.Modi, K.Deokule, A.Patel, H.Patki, O.Abuzaghleh // 2016 IEEE Long Island Systems, Applications and Technology Conference (LISAT).

5. Tkachov V. The Problem of Big Data Transmission in the Mobile "Multi-Copter - Sensor Network" System / V.Tkachov, V.Tokariev, V.Radchenko, V.Lebediev // Control, Navigation and Communication Systems. 2017. Issue 2. P. 154-157.

6. Pavlenko M. Hybrid model of knowledge for situation recognition in airspace. / $\mathrm{M}$. Pavlenko, A.Timochko, N.Korolyuk, M.Gusak //Automatic Control and Computer Sciences Volume 48, Issue 5, 2014, Pages 257-263.

7. Gonzales R.C. Digital image processing / R.C. Gonzales, R.E. Woods. - Prentice Inc. Upper Saddle River, New Jersey, 2002. - 779 p. $736 \mathrm{c}$.

8. Прэтт У. Цифровая обработка изображений: в 2 т.; пер. с англ. Москва: Мир, 1985.

9. Миано Дж. Форматы и алгоритмы сжатия изображений в действии: учеб. пособие; пер. с англ. Москва: Триумф, 2003. 336 с.

10. Захарченко М. В. Системи передавання даних / М.В. Захарченко, М.М. Гаджиєв, В.С. Басов, О.М. Мартинова та ін. // - Т.1: Завадостійке кодування: підручник [для студ. вищ. техн. навч. закл.]. / - Одеса «Фенікс», 2009. - 406 с.

11. Korchynskii V.V. The increase of transmission protection based on multiplexing of timer signal constructions / Korchynskii V.V., Kildishev V.I., Osadchuk E.А.// Зб. Наукові праці ОНАЗ, Одеса - ОНАЗ - 2018 - №1, - Р. 93-97.

12. Захарченко Н.В. Увеличение информационной емкости найквистового элемента при передаче 2-х символьных ансамблей таймерными сигналами / Н.В. Захарченко, В.В. Гордейчук, Е.А. Севастеев // “Сучасні інформаційні технології у сфері безпеки та оборони”. - К.: НУОУ ім. І. Черняховського - № 2(26) 2016 - С. $2126 .$.

13. Pavlenko, M., Kolmykov, M., Tymochko, O., Khmelevskiy, S., Larin, V. (2020). Conceptual Basis of Cascading Differential Masking Technology. 2020 IEEE 11th International Conference on Dependable Systems, Services and Technologies (DESSERT). doi: https://doi.org/10.1109/dessert50317.2020.9125024.

14. Tyurin, V., Martyniuk, O., Mirnenko, V., Open'ko, P., Korenivska, I. (2019). General Approach to Counter Unmanned Aerial Vehicles. 2019 IEEE 5th International Conference Actual Problems of Unmanned Aerial Vehicles Developments (APUAVD). doi: https://doi.org/10.1109/apuavd47061.2019.8943859. 


\section{References}

1. Larin V. Development of an advanced method of video information resource compression in navigation and traffic control systems. / S. Yevseiev, Ahmed Abdalla, S. Osiievskyi, V. Larin, M. Lytvynenko. // EUREKA: Physics and Engineering 5.(2020), P. 31-42. https://doi.org/ 10.21303/2461-4262.2020.001405.

2. Ruban I. Method of neural network recognition of ground-based air objects. / I.Ruban, K.Smelyakov, N.Bolohova // Proceedings of 2018 IEEE 9th International Conference on Dependable Systems, Services and Technologies, DESSERT 2018, pp. 589-592.

3. Sumtsov D. Development of a method for the experimental estimation of multimedia data flow rate in a computer network. / D.Sumtsov, S.Osiievskyi, V. Lebediev // Eastern-European Journal of Enterprise Technologies. Volume 2, Issue 2-92, 2018, Pages 56-64.

4. Mistry D. Network traffic measurement and analysis. / D.Mistry, P.Modi, K.Deokule, A.Patel, H.Patki, O.Abuzaghleh // 2016 IEEE Long Island Systems, Applications and Technology Conference (LISAT).

5. Tkachov V. The Problem of Big Data Transmission in the Mobile "Multi-Copter - Sensor Network" System / V.Tkachov, V.Tokariev, V.Radchenko, V.Lebediev // Control, Navigation and Communication Systems. 2017. Issue 2. P. 154-157.

6. Pavlenko M. Hybrid model of knowledge for situation recognition in airspace. / $\mathrm{M}$. Pavlenko, A.Timochko, N.Korolyuk, M.Gusak //Automatic Control and Computer Sciences Volume 48, Issue 5, 2014, Pages 257-263.

7. Gonzales R.C. Digital image processing / R.C. Gonzales, R.E. Woods. - Prentice Inc. Upper Saddle River, New Jersey, 2002. - 779 p.

8. Prett U. Tsifrovaya obrabotka izobrazheniy: v 2 t.; per. s angl. Moskva: Mir, 1985. 736 s.

9. Miano Dzh. Formaty i algoritmy szhatiya izobrazheniy v deystvii: ucheb. posobiye; per. s angl. Moskva: Triumf, 2003. 336 s.

10. Zakharchenko M. V. Systemy peredavannya danykh / M.V. Zakharchenko, M.M. Hadzhyyev, V.YE. Basov, O.M. Martynova ta in. // - T.1: Zavadostiyke koduvannya: pidruchnyk [dlya stud. vyshch. tekhn. navch. zakl.]. / - Odesa «Feniks», 2009. - 406 s.

11. Korchynskii V.V. The increase of transmission protection based on multiplexing of timer signal constructions / Korchynskii V.V., Kildishev V.I., Osadchuk E.A.// Zb. Naukovi pratsi ONAZ, Odesa - ONAZ - 2018 - №1, - P. 93-97.

12. Zakharchenko N.V. Uvelychenye ynformatsyonnoy emkosty naykvystovoho élementa pry peredache 2-kh symvol'nykh ansambley taymernymy syhnalamy / N.V. Zakharchenko, V.V. Hordeychuk, E.A. Sevasteev // "Suchasni informatsiyni tekhnolohiyi u sferi bezpeky ta oborony". K.: NUOU im. I. Chernyakhovs'koho - № 2(26) 2016 - S. 2126.

13. Pavlenko, M., Kolmykov, M., Tymochko, O., Khmelevskiy, S., Larin, V. (2020). Conceptual Basis of Cascading Differential Masking Technology. 2020 IEEE 11th International Conference on Dependable Systems, Services and Technologies (DESSERT). doi: https://doi.org/10.1109/dessert50317.2020.9125024.

14. Tyurin, V., Martyniuk, O., Mirnenko, V., Open'ko, P., Korenivska, I. (2019). General Approach to Counter Unmanned Aerial Vehicles. 2019 IEEE 5th International Conference Actual Problems of Unmanned Aerial Vehicles Developments (APUAVD). doi: https://doi.org/10.1109/apuavd47061.2019.8943859. 